HL 45.1 (2018): Article

This paper will appear in Historiographia Linguistica 45.1, August 2018.

\title{
August Schleicher and Materialism in 19th-Century Linguistics*
}

\author{
James McElvenny \\ University of Edinburgh
}

\section{Introduction}

August Schleicher (1821-1868) is a curious figure in the history of linguistics. From his own time to the present day he has enjoyed universal recognition for his technical innovations, which consolidated the field of Indo-European historical-comparative grammar. The reactions to his philosophical pronouncements on the nature of language, on the other hand, have generally ranged from simple rejection to outright ridicule. The peak of Schleicher's metaphysical excesses would have to be his claim that human languages are "natural organisms" that "came into being, grew and developed according to fixed laws and which in turn will age and die off" (Schleicher 1863: 7 [all translations are my own: JMc]). ${ }^{1}$

As is reflected in the title of the essay from which the words above are quoted - Die Darwinsche Theorie und die Sprachwissenschaft - the occasion for this most explicit formulation of Schleicher's metaphysical position was his first contact with the evolutionary theory of Charles Darwin (1809-1882). Subsequent scholarship on Schleicher has tended to focus on this Darwinian connection, even though it has long been established that Schleicher's views have other origins that pre-date his contact with Darwin's work and were in many respects quite different, even incompatible, with Darwinism (see Koerner 1989: 337355). Indeed, in the lively exchange between linguistic and biological theory in the 19th century, the balance of trade is generally in favour of the former (see Alter 1999).

The almost exclusive attention to the Darwinian perspective has obscured other features of Schleicher's historical context. For his critics in the world of mid- to late 19th-century linguistics in Germany, Schleicher was in the first instance not an adherent of Darwinism, but of 'materialism'. ${ }^{2}$ This is a charge levelled at Schleicher by his constant opponent H. Steinthal (1823-1899; e.g., Steinthal 1881: 47) and his otherwise sympathetic biographer Salomon Lefmann (1831-1912; e.g., Lefmann 1870: 73). In the following generation, the accusation was renewed by Georg von der Gabelentz (1840-1893) and Hugo Schuchardt (1843-1927; e.g., Schuchardt 1928 [1922]: 91-97), where it was extended to Schleicher's heirs, the Neogrammarians. Gabelentz commented:

It was a strange one-sidedness that wanted to align linguistics with the natural sciences. Admittedly, we cannot convince an unsophisticated materialism like that which just a few decades ago confused immature minds that not all science is natural science; and as Charles

\footnotetext{
* I would like to thank Nick Riemer, Bart Karstens, Jan Noordegraaf and the two anonymous referees for Historiographia Linguistica for their helpful feedback on earlier versions of this paper.

${ }^{1}$ Original: "Die Sprachen sind Naturorganismen, die [...] entstunden, nach bestimmten Gesetzen wuchsen und sich entwickelten und wiederum altern und absterben $[. .$.$] "$

${ }^{2}$ Desmet (1996) takes a much broader perspective on 'la linguistique naturaliste' in France, which in many ways took its cue from Schleicher. He examines at length the role played in France by French versions of scientific materialism.
} 
Darwin finally stepped forward with his epoch-making theory, even a serious linguist like

August Schleicher extended to him the hand of brotherhood. (Gabelentz 2016 [1891]: 15) ${ }^{3}$

In this paper, we explore the accusation of materialism made against Schleicher, what it meant, the ends it served, and whether it was in fact justified. We begin in section 2 with an examination of the aspects of Schleicher's theorizing that provoked the accusation. We then look in section 3 at the main criticisms embodied in the charge, with particular attention to the detailed critiques of Steinthal. In section 4, we identify Schleicher's place in relation to the politically engaged movement of scientific materialism. Section 5 turns to Schleicher's biography to show how his own political views, social background and personal experiences bound him to the movement. Finally, section 6 offers a conclusion.

\section{Morphology and Schleicher's philosophy of science}

Our point of departure in this paper, that most striking claim of Schleicher's that languages are natural organisms, is the conclusion he reaches at the end of a discussion of linguistic methodology. Schleicher praises linguists' increasing emulation of natural scientists' methods, an approach validated by the underlying commonality in kind between their respective objects of study. "From the natural scientists", Schleicher (1863: 6) insists, "we can learn to appreciate that only the fact established by secure, strictly objective observation and the correct conclusion built on this has any validity for science [...]". All scientists, linguists included, must limit themselves to "the precise observation of organisms and their laws of life", since "all talk, however ingenious, which slips away from this solid ground is devoid of any scientific value" (ibid., pp. 6-7). ${ }^{5}$

There are two pillars to Schleicher's scientific method as it is presented here, the empirical examination of the given 'organisms' of languages and the positing of 'laws of life' that govern their development. These are in turn the two points of contention targeted by the accusations of materialism. As we see in the following section, it was not so much distaste at Schleicher's biological phraseology that motivated these critiques as a thoroughgoing disagreement with the specific approach Schleicher took. In any case, these two principles have a long history in Schleicher's thought and had earlier found expression in different, nonbiological terms. As Koerner (1989: 343-355) shows, hints of these principles are apparent even in Schleicher's very first book, the 1848 Zur vergleichenden Sprachgeschichte, where they are couched in terms of idealist philosophy, while the explicit advocacy of a linguistics modelled on the natural sciences appears as early as in his second book, the 1850 Die Sprachen Europas in systematischer Übersicht.

\footnotetext{
${ }^{3}$ Original: "Eine seltsame Einseitigkeit war es, die Sprachwissenschaft den Naturwissenschaften einreihen zu wollen. Einem platten Materialismus, wie er noch vor wenigen Jahrzehnten unreife Köpfe verwirrte, ist freilich nicht einzureden, dass nicht alle Wissenschaft Naturwissenschaft sei; und als nun vollends Charles Darwin mit seiner epochemachenden Theorie hervortrat, da streckte ihm selbst ein ernsthafter Linguist wie August Schleicher die Bruderhand entgegen."

${ }^{4}$ Original: "Bei den Naturforschern kann man einsehen lernen, dass für die Wissenschaft nur die durch sichere, streng objective Beobachtung festgestellte Tatsache und der auf diese gebaute richtige Schluss Geltung hat [...]" ${ }^{5}$ Original: "Nur die genaue Beobachtung der Organismen und ihrer Lebensgesetze, nur die völlige Hingabe an das wissenschaftliche Object soll die Grundlage auch unserer Disciplin bilden; alles noch so geistreiche Gerede, das jenes festen Grundes enträth, ist jedes wissenschaftlichen Werthes bar und ledig."
} 
In Die Sprachen Europas, Schleicher (1850: 1-5) introduces a distinction between 'philology' (Philologie), which treats language as a means to understanding the mental and cultural life of its speakers, and 'linguistics' (Linguistik), which has "language as such" (die Sprache als solche) as its object of study. ${ }^{6}$ Language as such is part of the "natural history of man" (Naturgeschichte des Menschen) and because of this the method of linguistics is "completely different from that of all historical sciences and essentially aligns itself with the method of the other natural sciences" (ibid., p.2). ${ }^{7}$ Like the other natural sciences, linguistics is based on 'observation' (Beobachtung) and deals with an area ruled by "unchangeable natural laws" (unabänderliche natürliche Gesetze).

The aspect of language most clearly subject to natural laws, according to Schleicher (1850: 3-5), is the Formenlehre, for which he adopts the term 'Morphologie' in his 1859 essay 'Zur Morphologie der Sprache". In this essay, he sets out a system of formulae for describing the full range of morphological structures exhibited in the world's languages and in the process clearly circumscribes the limits of empirical scientific observation in linguistics. Morphology deals only with the "outer phonetic form of language" (äußere lautliche Form der Sprache). He envisaged a complementary discipline that would deal with the functions of these forms, but did not "dare for the moment to step into this area of research which penetrates into the innermost being of language, since [he] as yet lack[ed] guiding concepts and methods" (Schleicher 1859: 1). ${ }^{8}$ In the following years, however, Schleicher's methodological wariness solidified into ontology. In his 1865 essay "Über die Bedeutung der Sprache für die Naturgeschichte des Menschen”, the sequel to his 1863 Darwinian essay, Schleicher (1865a: 8) collapses language onto a single material plane: "Language is the symptom perceptible through the ear of the activity of a complex of material relations in the formation of the brain and the language organs with their nerves, bones, muscles etc." ${ }^{9}$ In the same year, he draws the consequences of this position for linguistics in his study of the Unterscheidung von Nomen und Verbum in der lautlichen Form:

The linguistic sound, the phonetic form of language, is the body, the phenomenon of the function, of the content of language. Neither appears separate from the other, they are always inseparably bound to one another. They are identical, even if of course not of the same kind. We have no right to assume functions where they are not indicated by sounds. Even in language the mind, the function, does not run independently of its body, the sound, but is always only really present in and through the latter. Our view of language is not dualistic, but rather monistic and we can consider only this [view] justified. (Schleicher 1865b: 502) ${ }^{10}$

\footnotetext{
${ }^{6}$ Schleicher later preferred the term Glottik to Linguistik as the name for this branch of language study (see Koerner 1989: 350, n.45). Glottik is used consistently from Schleicher (1859) onwards.

${ }^{7}$ Original: "Demzufolge ist auch die Methode der Linguistik von der aller Geschichtswissenschaften total verschieden und schliesst sich wesentlich der Methode der übrigen Naturwissenschaften an."

${ }^{8}$ Original: "In den kreiß diser ins innerste wesen der sprache vor dringenden forschung zu treten, wage ich zur zeit noch nicht, da es mir hier an leitenden grundanschauungen und an methoden noch gebricht."

${ }^{9}$ Original: "Die Sprache ist das durch das Ohr wahrnehmbare Symptom der Tätigkeit eines Complexes materieller Verhältnisse in der Bildung des Gehirns und der Sprachorgane mit ihren Nerven, Knochen, Muskeln u. s. f."

${ }^{10}$ Original: "Der sprachlaut, die lautliche form der sprache, ist der körper, die erscheinung der function, des inhaltes der sprache. Beide kommen nicht von einander getrennt vor, sie sind stäts untrenbar verbunden. Sie sind identisch, wenn auch natürlich nicht einerlei. Wir haben kein recht, functionen da vorauß zu setzen, wo keine lautform ir vorhandensein an zeigt. Auch in der sprache läuft nicht der geist, die function, unabhängig von seinem leibe, dem laute, sondern er ist nur in und durch letzteren wirklich vorhanden. Unsere anschauung vom
} 
Schleicher (1865b: 505-506) concludes: "We therefore maintain the conviction that nothing occurs in the speaker that is not expressed phonetically; that the sound is a fully valid and indeed the only witness of the function and that therefore a language only has those functions that it indicates phonetically." 11 That is, there is no inner life of language that is not immediately perceptible in its outer phonetic shell.

\section{Contemporary objections to Schleicher's philosophy of science}

At each step Schleicher took down the materialist path, he was met with opposition from Steinthal. The most direct and succinct formulations of this opposition appear in Steinthal's reviews of Schleicher's successive writings. Unfortunately, no dialogue ensued between the two: Schleicher is reputed to have said of Steinthal, "I don't read anything of his anymore" (Von dem lese ich nichts mehr [Lefmann 1870: 101]). But at least Steinthal's reviews leave us with one explicitly articulated side of the debate. Beginning with his review of Schleicher's (1859) 'Morphologie' essay, Steinthal attacks the two pillars of Schleicher's natural scientific approach to language study:

Herr Schleicher excludes from the very beginning [...] the historical movement of language, its development, from his consideration; and moreover he takes the study of the function of individual parts of the word and the word itself as a "complement of morphology" and does not "dare" to enter into this area of research [...] (Steinthal 1860: 434) ${ }^{12}$

Schleicher's exclusion of the "historical movement of language" rests on the second pillar of his scientific method as outlined in the previous section, adherence to unchangeable natural laws of development. His degradation of functions to a "complement of morphology" is of course a corollary of the first pillar, his singular concentration on perceptible outer form.

As with his treatment of functions, Schleicher did not so much exclude the historical development of forms in his 'Morphologie' essay as put it to one side. His morphological formulae were intended in the first instance to provide - in present-day parlance - a synchronic description of forms in languages without consideration of their history (see Schleicher 1859: 1). But it was only against the background assumption that languages develop according to an overarching deterministic plan that individual forms could be characterized as belonging to specific types. This is clear in Schleicher's popularizing 1860 Deutsche Sprache, which followed immediately after the 'Morphologie' essay, where Schleicher employs his formulae in a survey of morphological types in the world's languages and sketches the universal laws of growth and decline that govern the evolution from type to type (Schleicher 1860: 3-71). In opposition to Schleicher's view of development, Steinthal asserts a kind of historical particularism, in which every individual form has a unique identity that is the product of a complex developmental history involving the interaction of numerous

wesen der sprache ist keine dualistische, sondern eine monistische und nur dise können wir für berechtigt halten."

${ }^{11}$ Original: "Wir halten demnach an der überzeugung fest, daß nichts im sprechenden vor geht, was nicht lautlich auß gedrükt wird; daß der laut ein volgiltiger und zwar der einzige zeuge für die function ist und daß also eine sprache nur die functionen besizt, welche sie lautlich bezeichnet."

12 Original: "Herr Schleicher schliesst von vornherein [...] den geschichtlichen Gang der Sprache, ihre Entwicklung, von seiner Betrachtung aus; und ferner gilt ihm die Lehre von der Function der einzelnen Theile des Wortes und des Wortes selbst für eine ,Ergänzung der Morphologie', und er ,wagt' es nicht, in den Kreis dieser Forschung einzutreten $[\ldots]$ " 
internal and external factors. On Steinthal's view, it is impossible to consider a single form in any language as an instance of some pre-existing universally given type.

Steinthal (1860: 434) buttresses his historical particularism with a quotation from the Allgemeine Physiologie (1851) of Hermann Lotze (1817-1881), which in turn appeals to Wilhelm von Humboldt (1767-1835) to support the principle that "the form is at each moment the more immediate or distant result of functions - that is, not simply constant forces, but also processes and situations into which the parts that are taking shape are brought" (Lotze 1851: 324). ${ }^{13}$ This is a key doctrine of Lotze's 'functional morphology', in which he argued against the immanent determinism of contemporary theories of morphology in biology by pointing out the role played by external factors in shaping the ontogenetic development of living organisms (see Pester 1997: 169-184; cf. Beiser 2014: 62-70). We see in his invocation of Lotze's Allgemeine Physiologie that Steinthal's objections were not so much targeted against the importation of concepts and methods from the natural sciences as against the specific brand of 'morphology' that Schleicher sought to adopt. Citing Lotze's example here as well, Steinthal (1860: 433) makes the case that even "morphology in natural science is still today little more than a desideratum" (die Morphologie in der Naturwissenschaft [... ist] bis heute noch wenig mehr als ein Desideratum).

It should be noted that Steinthal's arguments were also not directed at the formalizing enterprise in general. Indeed, Steinthal was apt to indulge in formalization himself: his 'psychological formulae' (psychologische Formeln) were an attempt to formalize the associative psychology of Johann Friedrich Herbart (1776-1841), on which he built much of his own theoretical apparatus. Steinthal always remained cautious about pressing the claims of his system, however. In introducing a formalization of the psychological process of 'apperception', Steinthal (1881: 198) commented: "Let us now represent the process of apperception in a psychological formula. Even if we do not flatter ourselves that we have created a mathematical psychology in this way, such formulae must promote clarity."14 Steinthal never ventured to offer a comprehensive, systematic account of his formulae although his pupil Gustav Glogau (1844-1894) did try to meet this challenge (Glogau 1876) - and only ever used the formulae in a sporadic, ad hoc way in his writings.

The core issue in Steinthal's critique is therefore Schleicher's reduction of the study of language, in both the source of its data and its explanatory horizon, to "the barest outer appearances [...] the empty shell of language" (die barste Aeußerlichkeit [...] die leere Schale der Sprache [Steinthal 1860: 434]). Schleicher's subsequent move to simply conflate outer linguistic forms with their inner properties confirmed Steinthal's greatest fears. In his review of Schleicher's (1865b) Unterscheidung von Nomen und Verbum in der lautlichen Form, Steinthal (1865) insists that the outer form of language does not stand for itself; there is indeed much that goes on in the minds of speakers which finds no phonetic expression. The linguist's task is to interpret the outer form in order to discover the inner form:

\footnotetext{
${ }^{13}$ Original: “daß die Form in jedem Augenblicke das nähere oder entferntere Resultat von Functionen ist, d.h. nicht bloß beständigen Kräften, sondern auch von Processen und Lagen, in welche die sich bildenden Theile gebracht sind."

${ }_{14}$ Original: "Versuchen wir den Apperceptions-Process in einer psychologischen Formel darzustellen. Schmeicheln wir uns auch nicht, dass damit eine mathematische Psychologie geschaffen werde, so muss doch solche Formeln die Klarheit fordern."
} 
When we say [the German expressions], "red today, dead tomorrow", "learnt in youth, done in age", the opposition and comparison do not lie in the expression, but the mind attributes that which is not in the linguistic expression by tracing each word back to the intuition that underlies it [...] So some things do indeed occur in the mind that are not expressed in the sound, but which the sound prompts the mind [to think of], since they are indeed included in that which the sound indicates. (Steinthal 1865: 506)

While in his reviews Steinthal $(1860,1865)$ does not employ the term 'materialism', he brings this label into play in later writings to describe just those aspects of Schleicher's thought criticized in his reviews. In his Abriss der Sprachwissenschaft, for example, Steinthal (1881: 47) comments that Schleicher, "in connection with modern materialism, made the assertion that the mind or the thought or the content of language is the function of the sound". ${ }^{16}$ This is the same argument that Lefmann had made some ten years earlier in calling Schleicher a materialist:

Nothing is in language and nothing exists in the feeling of the speaker that is not expressed phonetically. Schleicher uttered this sentence and in doing so stated the alpha and omega, so to speak, of his 'monistic' or rather materialist underlying philosophy. (Lefmann 1870: 73) 17 $^{17}$

The accusation of 'materialism' was then not born of an in principle objection to analogies between linguistics and the natural sciences, but was rather originally directed at the specific natural scientific approach Schleicher sought to emulate in his linguistic morphology. Schleicher's morphology and the biological approaches that inspired it reduced their objects of study to their perceptible outer forms and the scope of their explanations to descriptive statements about appearance and change in appearance.

\section{Materialism in context}

As Lefmann acknowledges in the quotation above, Schleicher actually refused the label 'materialism' and preferred to describe his philosophy as a kind of 'monism'. Materialism implies that matter is privileged over other kinds of substance, argues Schleicher (1863: 8), while in monism "there is neither mind nor matter in the usual sense, but rather just one thing that is both at the same time." ${ }^{18} \mathrm{He}$ adds: "To accuse this view that rests on observation of materialism is just as preposterous as to accuse it of spiritualism" (ibid., p.9, n.1). ${ }^{19}$ These protestations are not simply terminological quibbling on Schleicher's part, but rather represent manoeuvring around ideologically occupied terrain. In the second half of the 19th century,

\footnotetext{
${ }^{15}$ Original: "Wenn wir sagen: ,heute roth, morgen todt', ,jung gewohnt, alt gethan', so liegt im Ausdruck nicht Gegensatz und nicht Vergleichung; aber was nicht im sprachlichen Ausdruck liegt, denkt dennoch der Geist hinzu, indem er jede Worte auf die zu Grunde liegende Anschauung zurückführt [...] Es geht also thatsächlich manches im Geiste vor, was nicht im Laute ausgedrückt ist, wozu ihn dennoch der Laut veranlaßt, weil es thatsächlich in dem eingeschlossen ist, was der Laut bezeichnet."

${ }^{16}$ Original: "[...] wollte man nun, in Anschluss an den heutigen Materialismus, die Behauptung aufstellen [Fußnote: Das hat S c h 1 e i c h e r getan.], der Geist oder der Gedanke oder der Inhalt der Sprache sei die Function des Lautes."

${ }^{17}$ Original: "Nichts ist in der Sprache und nichts existiert im Gefühle des Sprechenden, was nicht lautlich ausgedrückt wird. Schleicher hat diesen Satz ausgesprochen und damit, so zu sagen, das Alpha und Omega seiner ,monistischen' oder geradezu materialistischen Grundanschauung."

${ }^{18}$ Original: "[ ...] es gibt weder Geist noch Materie im gewöhnlichen Sinne, sondern nur eines, das beides zugleich ist."

${ }^{19}$ Original: "Diese auf Beobachtung beruhende Ansicht des Materialismus zu beschuldigen, ist eben so verkehrt, als wollte man sie des Spiritualismus zeihen."
} 
materialism became inseparable from radical politics and an anti-religious stance. We may ask where Schleicher stood in relation to these ideological debates.

Three names that feature prominently in Schleicher's (1863) essay Die Darwinsche Theorie und die Sprachwissenschaft provide us with the means to triangulate his position in the contemporary intellectual landscape. The first two are those of Matthias Schleiden (18041881) and Carl Vogt (1817-1895), whose Wissenschaftliche Botanik (Schleiden 1842) and Physiologische Briefe (Vogt 1847) Schleicher (1863: 6) cites as his chief sources of instruction about Entwicklungsgeschichte; that is, developmental or evolutionary history. The third name is that of Ernst Haeckel (1834-1919), to whom the essay is dedicated: it was Haeckel who recommended Schleicher read Darwin's Origin of Species in its first German translation (Darwin 1860 [1859]) and thereby prompted him to write the essay (see Schleicher 1863: 3). All three of these names are deeply bound up with scientific materialism, a movement in 19th-century Germany centred around a reductionist biology that recognized only physical matter and mechanical forces and as a result rejected such traditional entities as vital forces, the mind and soul. Scientific materialism was no timid and remote pastime of the ivory tower: the most vocal members of the movement weaponized their science and wielded it against political conservatism and religion (see Gregory 1977; Beiser 2014: 53-96).

Within the confines of the laboratory, a mild form of materialism was a logical consequence of the great scientific leaps achieved by a commitment to empirical observation. Above all in biology, observable matter and mechanical interactions were in many cases now enough to explain phenomena for which vital forces had previously been invoked. As an unobservable deus ex machina, such forces now seemed incurably speculative and superfluous. Exemplified in his Wissenschaftliche Botanik, among other texts, Schleiden's pioneering work on cell theory served as an inspiration to materialism: taking advantage of the latest advances in microscopy, he formulated a sober, empirically minded account of the organism as a conglomeration of cellular machines. Schleiden (e.g., 1844) was himself not averse to defending his empiricism and philosophical agnosticism against attacks from the rival romantic tradition of Naturphilosophie, although the later aggressive intrusion of scientific materialism into religious and political spheres was too much for him: Schleiden (1863) later completely disavowed the movement.

Vogt and Haeckel, by contrast, were in the vanguard of evangelical materialism in their respective periods, and did much to shape its aggressive and political character. Vogt may be counted as one of the chief instigators of scientific materialism and his Physiologische Briefe as one of the movement's defining texts. Originally serialized in the Augsburger Allgemeine Zeitung from 1845 to 1847 , the Physiologische Briefe offered an overview of the latest advances in the life sciences to the general public. Over the years in which they appeared, the emphasis on material processes, the straying into questions of the mind and soul, and the polemical tone with respect to traditional explanations became more marked. Vogt wrote the Briefe during a three-year stay in Paris, in which he fraternized with such figures as the Russian anarchist Michail Bakunin (1814-1876) and the German revolutionary poet Georg Herwegh (1817-1875), among many others. ${ }^{20}$ His 1848 Ocean und Mittelmeer, an account of

\footnotetext{
${ }^{20}$ Another of Vogt's acquaintances in Paris was Karl Marx (1818-1883), with whom Vogt quickly developed a relationship of mutual hatred. From their time in Paris to the end of their respective lives, Marx showed little
} 
the research expeditions he undertook with these two companions, draws at many points explicit connections between his science and his increasingly radical political views (cf. Gregory 1977: 58-69).

When the Europe-wide revolution of 1848 came to the German-speaking lands, Vogt had already returned from across the Rhine, and was now the newly appointed Professor of Zoology in Gießen. In the German revolution, bourgeois forces rose up to demand constitutional government and national unity in a country that was at this time still made up of a patchwork of states, small and large, ruled by assorted kings, dukes, princes and their aristocratic cliques. With particularly strong support from the students in Gießen, Vogt was elected to the national parliament that came together in Frankfurt am Main in 1848, where he advocated an uncompromising radical liberal position. After the failure of the revolution, he went into exile in Switzerland, where his political venom steadily increased in potency (see Gregory 1977: 69-70).

Haeckel, like Schleicher, rejected the label materialism for his philosophy and preferred the term monism. In fact, Haeckel cited Schleicher — alongside Johann Wolfgang von Goethe (1749-1832), who famously advanced a biological theory of morphology - as one of the main inspirations of his thought, and ultimately traced his philosophical genealogy back to the monistic pantheism of Baruch Spinoza (1632-1677; see Richards 2008: 124-128). Despite his protestations, Haeckel's contemporary critics generally saw in him the successor of the crusading materialism of the previous generation, and he certainly cultivated the polemical spirit that term had come to imply. The high point of his polemic came at the end of the century, in his 1899 popularizing — and extremely popular — book Die Welträthsel, a manifesto of the monistic world view (cf. Richards 2008: 398-403). The title is a reference to Emil du Bois-Reymond's (1818-1896) speech "Die sieben Welträthsel" (Du Bois-Reymond 1882 [1880]), in which he sketched seven metaphysical questions that he supposed natural science would never be able to answer. In responding to Du Bois-Reymond, Haeckel did not confine himself to the philosophical plane, but insisted on the social and political relevance of his project:

Our political order will only improve when it is freed from the shackles of the [Catholic] Church and when it raises its citizens' knowledge of the world and of mankind to a higher level through general education in the sciences. (Haeckel 1905 [1899]: 10-11) ${ }^{21}$

When Haeckel first wrote these words in 1899, German unification had been a reality for nearly thirty years, although not brought about through democratic striving from below but imposed from above through Prussian power. By the time Otto von Bismarck (1815-1898), the chancellor of German unification, was forced out of office in 1890, his Realpolitik had successfully established a conservative equilibrium, beating off challenges from all sides. Although Bismarck himself had reached an entente with the Catholic Church by 1879, ending the hard-fought Kulturkampf, the Church remained for radical liberals like Haeckel the

restraint in denouncing the bourgeois liberalism of Vogt's materialism - which of course was of a very different kind from Marx' own dialectical materialism - and even tried to publicly destroy Vogt's personal reputation (see Gregory 1977: 198-204).

${ }^{21}$ Original: "Unsere Staatsordnung kann nur dann besser werden, wenn sie sich von den Fesseln der Kirche befreit, und wenn sie durch allgemeine naturwissenchaftliche Bildung die Welt- und Menschenkenntnis der Staatsbürger auf eine höhere Stufe hebt." 
primary representative of religious obscurantism (see Gross 2004). Haeckel's ultimate solution, with which he concludes the Welträthsel, is a proposal for a monistic religion and ethics reminiscent of Auguste Comte's (1798-1857) religion of positivism. In aid of monistic enlightenment, Haeckel founded the 'Monistenbund' in 1906, which brought together a diverse spectrum of scientists and scholars who all subscribed to Haeckel's program to varying degrees (see Richards 2008: 371-372).

Schleicher was steeped in this thought emanating from figures like Schleiden and Vogt and continued by Haeckel, in part through his own interests in the natural sciences, in particular botany, and in part through immediate personal contact. From childhood Schleicher had been a keen amateur botanist, an interest that was encouraged by his physician father (see Lefmann 1870: 66). Schleicher (1860: 3) commented himself that Haeckel most probably had his "horticultural and botanical hobbies" (gärtnerischen und botanischen Liebhabereien) in mind when he recommended reading Darwin's Origin of Species, which Schleicher (1864) also reviewed from a horticultural perspective for the Zeitschrift für deutsche Landwirthe. Both Schleiden and Haeckel were colleagues of Schleicher at the University of Jena, with whom he cultivated personal relationships: Schleiden was Professor of Botany from 1839 to 1863, overlapping with Schleicher in the period 1857-1863, and Haeckel was in Jena from 1861 until the end of his career, beginning with his Habilitation and eventually rising to Professor of Zoology, among other roles. Vogt was never a personal acquaintance of Schleicher's but, as we see in more detail in the following section, Schleicher was a correspondent of the Augsburger Allgemeine Zeitung in the same period in which Vogt's Physiologische Briefe appeared in that newspaper.

There is of course the possibility that Schleicher's commitment to these thinkers was merely a scientistic veneer on an existing body of methods and philosophy of science internal and native to linguistics. On a purely methodological level, a concentration on the perceptible outer forms of languages and the postulation of principles that do not go beyond describing changes from one historical form to another became firmly established in Indo-European comparative grammar in the wake of Franz Bopp's (1791-1867) pioneering work. Bopp himself continued to entertain a broad-ranging conception of language (see Karstens 2012), but the nascent field of comparative grammar was nourished by his clinical dissection and comparison of outer forms and the investigation of the "physical and mechanical laws" (physischen und mechanischen Gesetze [Bopp 1833: iii]) governing them. This methodological coincidence between avowedly empirical approaches in the natural sciences and historical-comparative linguistics is commented on by Gabelentz in his critique of Schleicher's materialism:

It is indeed true that that inductive method of the language scholar is exactly the same as that of the natural scientist. But we do not name the scientific worker according to the tool that he uses, but rather according to the stuff on which he works - and this is truly different enough. (Gabelentz 2016 [1891]: 16) ${ }^{22}$

\footnotetext{
${ }^{22}$ Original: "Es ist ja wahr, die inductive Methode des Sprachforschers ist mit der des Naturforschers völlig gleich. Aber man nennt den wissenschaftlichen Arbeiter nicht nach dem Werkzeuge, das er führt, sondern nach dem Stoffe, den er bearbeitet, - und der ist wahrlich verschieden genug."
} 
Morpurgo Davies' (1998: 198) rationalization of what she sees as Schleicher's contorted metaphysics similarly supposes that his theory is simply a skin stretched across his existing technical skeleton: "It now becomes clear (to the historical linguist at least) that the 'theory' must be taken in conjunction with the actual results of the concrete historical and comparative work which it serves to justify." The tenets of materialism or monism may have therefore merely been the best philosophical fit for Schleicher's established day-to-day practice.

Indeed, in his earliest works Schleicher's philosophical allegiances seem to lie elsewhere. As observed in section 2 above, the key elements later criticized as constituting Schleicher's materialist position, immanent laws of development and focus on outer form, were already present in his first book, the 1848 Zur vergleichenden Sprachgeschichte. But there Schleicher (1848: 20) assimilates the notion of laws of development to the laws of history of the idealist philosopher Georg Wilhelm Friedrich Hegel (1770-1831). Koerner (1989: 348) hypothesizes that Schleicher's engagement with Hegel — in particular with Hegel's Naturphilosophie may have in fact stimulated his natural scientific thinking and helped him on his later course. This hypothesis is quite plausible: although the older Naturphilosophie was generally denounced by the champions of mechanistic science, they maintained many of its principles in modified form. Richards (2008: 118-124), for example, shows how teleological laws of development postulated in varieties of Naturphilosophie, in particular Goethe's morphology, were reinterpreted by Haeckel in his general morphology as emergent properties of more fundamental mechanical laws. Schleicher's natural laws of development in language make a similar migration from the ideal to the material realm with his shift from Hegel to natural scientific models.

Schleicher's philosophical views are therefore the product of many different influences. However, he was still indisputably embedded in the contemporary movement of scientific materialism. Schleiden, Vogt and Haeckel, the three thinkers shaping his Darwinsche Theorie, were all key contributors to the development of scientific materialism, whether they embraced or - like Schleicher - rejected the label. Furthermore, as the example of Haeckel shows, an initial engagement with idealist positions did not preclude - and could even serve as a bridge - to materialist ideas.

\section{Politics and religion}

The political baggage attached to the term 'materialism' enhanced its impact as a denunciation in what should have otherwise been strictly scientific debates, and this no doubt encouraged its use in critiques of Schleicher's theories. But there is also a legitimate question as to what extent Schleicher was driven by political motivations. On the surface, Schleicher's linguistics tends towards the technical and seems at most to sublimate any broader concerns. His most overtly political work is his Deutsche Sprache (1860: v-vi), which "has not a scholarly but rather a national purpose" to contribute to the "clarification of the German national consciousness and strengthening of the German national feeling". ${ }^{23}$ Such sentiments definitely accord with the German liberalism of the time, but are not enough on their own to

\footnotetext{
${ }^{23}$ Original: “[...] es [das Buch Die Deutsche Sprache] hat keinen gelehrten, sondern nur einen nationalen Zweck. [...] daß sie [die Schrift] zur Klärung des deutschen Volksbewustseins und zur Kräftigung des deutschen Nationalgefühles ein wenn auch geringes Scherflein beiträgt [...]"
} 
place Schleicher in any specific camp. Various biographical details do, however, reveal that Schleicher did indeed belong to the same political milieu that gave rise to materialism.

As with his interest in the natural sciences, Schleicher's political formation can be traced back to his childhood: Schleicher's father was active in the contemporary bourgeois-liberal milieu and was even one of the founding members of the original Burschenschaft in Jena (see Dietze 1966: 15-16). The Burschenschaften were student organizations that campaigned for German unification against the conservative forces of the German aristocracy. As a student in Leipzig, Tübingen and Bonn from 1840 to 1846, Schleicher was himself active in the Burschenschaften and the ideologically aligned Turnvereine (gymnastics clubs). In fact, the venue in which Schleicher and Haeckel later made their acquaintance was the Turnverein at the University of Jena, which Schleicher led (see Richards 2008: 83).

Following the completion of his doctorate in 1846, Schleicher spent several years travelling around western and central Europe. Through his connections with the radical liberal milieu in Bonn, Schleicher was given the role of political correspondent for the Kölnische Zeitung and the Augsburger Allgemeine Zeitung, for both of which he reported on the Austrian parliament that in the wake of the 1848 revolution met in the Moravian city of Kroměřiž (see Syballa 1995: 13-27, which includes an index of Schleicher's articles). The parliament was ultimately dissolved by the Austrian Kaiser and his ministers, who resolved to restore the old absolutist order and fight liberalism through repression. Although Friedrich Bodenstedt (1819-1892), an acquaintance of Schleicher's from his time in Kroměříž, later reported that Schleicher took little interest in politics and only worked as political correspondent so he could travel to Slavic lands and learn their languages (see Syballa 1995: 14; Dietze 1966: 22-23), Schleicher's articles from this time evince a strong sympathy for the liberal cause. For the Austrian authorities, too, Schleicher's articles were sufficiently incendiary to warrant interception in the post, even though other correspondents for the Kölnische Zeitung and Augsburger Allgemeine Zeitung continued to report from Austrian territory unhindered. By 1849 the Austrian authorities' pressure on Schleicher grew to the point that he felt compelled to flee from Prague by night in order to escape his anticipated arrest (Syballa 1995: 22).

But in the following year, 1850, Schleicher returned to Prague, where he stayed until 1857. One progressive concession of the Austrian authorities to the 1848 revolution was to institute a reform of the Austrian education system, for which many professors had to be brought in from abroad. On the recommendation of Georg Curtius (1820-1885), Schleicher was called to Prague as an Extraordinary Professor, a major leap in his academic career (Syballa 1995: 2829); in 1853 he was promoted to Ordinarius. Schleicher did not enjoy his time in Prague: in rather immoderate memoires (published in Syballa 1995: 100-112), Schleicher not only laments the perceived poor quality of his students and colleagues but also complains of the oppressive political atmosphere of post-1848 Austria. In the effective police state that existed at this time, he faced constant harassment from the authorities, who held him in suspicion for his former work as political correspondent (see Syballa 1995: 48-55). The police placed him under observation and at one point even searched his house. A sensationalized - and, according to Syballa (1995: 48-49), apocryphal — version of Schleicher's troubles, first recorded in Lefmann's (1870: 37) biography, even has Schleicher being deported for a time to Vienna. 
In 1857 Schleicher left Prague for an insecure and lowly paid position as Honorarprofessor in Jena. The position had been arranged for him by a friend at the university, whom Schleicher had begged for help two years earlier. The final trigger that led to Schleicher's decision to abandon Prague was personal tragedy — the death of his newborn son in 1855 (Syballa 1995: 54-55) - but this came on top of his ongoing dissatisfaction and discomfort there. His political views - and the suffering he experienced because of them were unquestionably a factor in his flight from Prague and his later unwillingness to move away from Jena, despite his poor position at the university there. At the end of Prague memoires, Schleicher (in Syballa 1995: 112) clearly marks himself as a nationally minded, anti-Catholic German liberal: "I have learnt some things in Austria, good and bad, but the best thing that I learnt there is the deep appreciation of my German homeland and of my luck in being the child of Protestant parents." 24

In subsequent years, Schleicher refused calls to professorships in Warsaw, St. Petersburg and Dorpat (present-day Tartu, Estonia), all of which were at that time part of the Russian Empire. In refusing the call to Dorpat in 1863, Schleicher wrote the following justification to his friend Reinhold Köhler (1830-1892):

That for a' that an' a' that I gave up Warsaw back then was definitely one of the few clever tricks that I have ever pulled. I'll let that be a lesson to me and I never want to turn my back on Germany. The way things are now, anyone can consider themselves lucky if they are not a civil servant in either Prussia or Austria but rather enjoy the noble freedom of the derided pirate states. (Schleicher to Köhler, 4 March 1863, quoted from Dietze 1966: 47; complete letter in Dietze 1960: 278) ${ }^{25}$

By his own account, Schleicher preferred the "noble freedom" of the "derided pirate states" that is, the small and comparatively liberal independent states of Central Germany, such as the Duchy of Saxe-Weimar-Eisenach, in which Jena was located - to the hulking, backward empires of Austria, Prussia, and Russia. ${ }^{26}$ Particularly revealing is his choice of words in opening the letter - "for a' that an' a' that" (trotz alledem und alledem) - a catchphrase derived from the poem "Trotz alledem" by Ferdinand Freiligrath (1810-1876). Originally a translation of Robert Burns' (1759-1796) "Is there for an honest poverty" (also known under the title "A man's a man for a' that"), Freiligrath later rewrote his poem as a commentary on the events of 1848. Since that time, it has been constantly redeployed and reworked in support of diverse progressive political causes (see Robb \& John 2011).

Although Schleicher himself was no protagonist in the political and religious crusades of the materialists, he was immersed in the same radical liberal milieu from which their ideology emerged. The persecution he faced for these connections in post-1848 Austria led him to

\footnotetext{
${ }^{24}$ Original: "Ich habe manches in Österreich gelernt, Gutes und Schlimmes, das Beste aber, was ich dort gelernt habe, ist die innige Wertschätzung meiner deutschen Heimat und des Glückes, evangelischer Eltern Kind zu sein."

${ }^{25}$ Original: " $\mathrm{Da} \beta$ ich trotz alledem und alledem Warschau damals aufgab, war allerdings einer der wenigen gescheiten Streiche die ich je ausgeführt. Ich lasse mir das eine Lehre sein und will niemals Deutschland den Rücken kehren. Wie die Dinge jetzt stehen, so kann sich jeder nur Glück wünschen, der weder in Preußen noch in Österreich Beamter ist, sondern der edeln Freiheit der verspöttelten Raubstaaten genießt." Note that professors in the German-speaking countries then as now are considered civil servants.

${ }^{26}$ One of Schleicher's later letters to Köhler (published in Dietze 1960: 279-280) indicates that Schleicher may have been prepared to compromise on his anti-Prussian sentiment. After the death of Franz Bopp in 1867, Schleicher lamented that he would not be called to Bopp's former chair in Berlin.
} 
prefer a life of some financial hardship on the institutional margins of the University of Jena to a prestigious professorship in a reactionary state like Austria, Prussia, or Russia.

\section{Concluding observations}

What we today generally refer to as Schleicher's 'Darwinian' linguistics was for his German contemporaries not so much a manifestation of Darwinism as of 'materialism'. Schleicher rejected the label materialism, however, and preferred to describe his views as a variety of 'monism'. But the intellectual genealogy that Schleicher traced for himself places him squarely in the tradition of the contemporary German movement of scientific materialism. What must be taken into account is that the choice of label was no simple matter of abstract philosophical convictions: 'materialism' was in this period inextricably associated with radical liberal politics and its accompanying anti-religious sentiment. The accusation of materialism in a scientific debate therefore came armed with political barbs. Even though Schleicher was comparatively muted in employing his science in the service of politics, he did indeed belong to the same radical milieu from which the representatives of political materialism came. His invocation of materialist doctrines therefore resulted not only from his philosophy of science, but was also a product of his political views and social background.

\section{REFERENCES}

Alter, Stephen G. 1999. Darwinism and the Linguistic Image: Language, race, and natural theology in the nineteenth century. Baltimore, Md.: Johns Hopkins University Press.

Beiser, Frederick C. 2014. After Hegel: German philosophy 1840-1900. Princeton: Princeton University Press.

Bopp, Franz. 1833. Vergleichende Grammatik des Sanskrit, Zend, Griechischen, Lateinischen, Litthauischen, Gothischen und Deutschen, vol. I. Berlin: Akademie der Wissenschaften.

Darwin, Charles. 1860 [1859]. Die Entstehung der Arten im Thier- und Pflanzen-Reich durch natürliche Züchtung. Translated by Heinrich Georg Bronn. Stuttgart: Schweizerbart.

Desmet, Piet. 1996. La linguistique naturaliste en France (1867-1922). Leuven: Peeters.

Dietze, Joachim. 1960. „Die Briefe August Schleichers an Reinhold Köhler“. Zeitschrift für Slawistik 5, 267-280.

Dietze, Joachim. 1966. August Schleicher als Slawist: sein Leben und sein Werk in der Sicht der Indogermanistik. Berlin: Akademie Verlag.

Du Bois-Reymond, Emil. 1882 [1880]. "Die sieben Welträthsel". Über die Grenzen des Naturerkennens, Die sieben Welträthsel, zwei Vorträge, ed. by Emil Du Bois-Reymond, 58-111. Leipzig: Veit \& Comp.

Gabelentz, Georg von der. 2006 [1891]. Die Sprachwissenschaft, ihre Aufgaben, Methoden und bisherigen Ergebnisse, ed. by Manfred Ringmacher and James McElvenny. Berlin: Language Science Press.

Glogau, Gustav. 1876. Steinthals Psychologische Formeln zusammenhängend entwickelt. Berlin: Ferdinand Dümmler.

Gregory, Frederick. 1977. Scientific Materialism in Nineteenth Century Germany. Dordrecht: Reidel.

Gross, Michael B. 2004. The War against Catholicism: liberalism and the anti-Catholic imagination in nineteenth-century Germany. Ann Arbor: University of Michigan Press.

Haeckel, Ernst. 1866. Generelle Morphologie der Organismen. Berlin: Reimer.

Haeckel, Ernst. ${ }^{9} 1905$ [1899]. Die Welträthsel, gemeinverständliche Studien über monistische Philosophie. Stuttgart: Alfred Kröner.

Karstens, Bart. 2012. "Bopp the Builder. Discipline formation as hybridization: the case of comparative linguistics". The Making of the Humnanities, vol. II: from early modern to modern disciplines, ed. by Rens Bod, Jaap Maat and Thijs Weststeijn, 103-137. Amsterdam: Amsterdam University Press. 
Koerner, E. F. Konrad. 1989. "August Schleicher and Linguistic Science in the Second Half of the 19th Century". Practicing Linguistic Historiography by E.F.K. Koerner, 324-375. Amsterdam \& Philadelphia: John Benjamins.

Lefmann, Salomon. 1870. August Schleicher: Skizze. Leipzig: Teubner.

Lotze, Hermann. 1851. Allgemeine Physiologie des koerperlichen Lebens. Leipzig: Weidmann'sche Buchhandlung.

Morpurgo Davies, Anna. 1998. History of Linguistics, vol. IV: Nineteenth-century linguistics. London: Longman.

Pester, Reinhardt. 1997. Hermann Lotze: Wege seines Denkens und Forschens; ein Kapitel deutscher Philosophie- und Wissenschaftsgeschichte im 19. Jahrhundert. Würzburg: Königshausen \& Neumann.

Richards, Robert J. 2008. The Tragic Sense of Life: Ernst Haeckel and the struggle over evolutionary thought. Chicago: University of Chicago Press.

Robb, David and Eckhard John. 2011. "A man's a man for a' that' and 'Trotz alledem': Robert Burns, Ferdinand Freiligrath, and their reception in the folksong movement". Modern Language Review 106:1.17-46.

Schleicher, August. 1848. Zur vergleichenden Sprachgeschichte. Bonn: König.

Schleicher, August. 1850. Die Sprachen Europas in systematischer Übersicht. Bonn: König. (New ed., with an Introduction by Konrad Koerner, Amsterdam \& Philadelphia: John Benjamins, 1983.)

Schleicher, August. 1859. "Zur Morphologie der Sprache". Mémoires de l'Académie Impériale des Sciences de St.-Petersbourg I:7.1-38.

Schleicher, August. 1860. Die Deutsche Sprache. Stuttgart: Cotta.

Schleicher, August. 1863. Die Darwinsche Theorie und die Sprachwissenschaft, offenes Sendschreiben an Herrn Dr. Ernst Haeckel, o. Professor der Zoologie und Direktor des zoologischen Museums an der Universität Jena. Weimar: Hermann Böhlau.

Schleicher, August. 1864. "Die Darwin'sche Theorie und die Thier- und Pflanzenzucht". Zeitschrift für deutsche Landwirthe 15.1-11.

Schleicher, August. 1865a. Über die Bedeutung der Sprache für die Naturgeschichte des Menschen. Weimar: Hermann Böhlau.

Schleicher, August. 1865b. Die Unterscheidung von Nomen und Verbum in der lautlichen Form. Leipzig: S. Hirzel.

Schleiden, Matthias. 1842. Grundzüge der wissenschaftlichen Botanik. Leipzig: Engelmann.

Schleiden, Mattthias. 1844. Schelling's und Hegel's Verhältniss zur Naturwissenschaft. Leipzig: Engelmann.

Schleiden, Matthias. 1863. Ueber den Materialismus der neueren deutschen Naturwissenschaft, sein Wesen und seine Geschichte. Leipzig: Engelmann.

Schuchardt, Hugo. 1928 [1922]. Hugo Schuchardt-Brevier: Ein Vademecum der allgemeinen Sprachwissenschaft. Ed. by Leo Spitzer. Halle/Saale: Max Niemeyer.

Steinthal, H. 1860. "Mathematische Sprachwissenschaft". Zeitschrift für Völkerpsychologie und Sprachwissenschaft 1.432-435.

Steinthal, H. 1865. Review of Die Unterscheidung von Nomen und Verbum in der lautlichen Form by Schleicher. Zeitschrift für Völkerpsychologie und Sprachwissenschaft 3.497-506.

Steinthal, H. 1881. Abriss der Sprachwissenschaft: Erster Teil, die Sprache im Allgemeinen. Berlin: Ferdinand Dümmler.

Syballa, Theodor. 1995. August Schleicher und Böhmen. Prague: Unverzita Karlova v Praze.

Vogt, Carl. 1847. Physiologische Briefe für Gebildete aller Stände. Stuttgart: Cotta'scher Verlag.

Vogt, Carl. 1848. Ocean und Mittelmeer. Reisebriefe. 2 vols. Frankfurt am Main: Literarische Anstalt.

\section{SUMMARY}

Towards the end of his career, August Schleicher (1821-1868), the great consolidator of Indo-European historical-comparative linguistics in the mid-19th century, famously drew explicit parallels between linguistics and the new evolutionary theory of Darwinism. Based on this, it has become customary in linguistic historiography to refer to Schleicher's 'Darwinian' theory of language, even though it has long been established that Schleicher's views have 
other origins that pre-date his contact with Darwinism. For his contemporary critics in Germany, however, Schleicher's thinking was an example not of Darwinism but of 'materialism'. This article examines what 'materialism' meant in 19th-century Germany — its philosophical as well as its political dimensions - and looks at why Schleicher's critics applied this label to him. It analyses the relevant aspects of Schleicher's linguistics and philosophy of science and the criticisms directed against them by H. Steinthal (1823-1899). It then discusses the contemporary movement of scientific materialism and shows how Schleicher's political views, social background and personal experiences bound him to this movement.

\section{RÉSUMÉ}

Dans son œuvre tardive, August Schleicher (1821-1868), qui est considéré un personnage-clé des études indo-européennes au milieu du XIXe siècle, entreprit une célèbre tentative de tirer des parallèles entre la linguistique et la théorie de l'évolution de Darwin qui, à l'époque, était encore neuve. Par la suite, il est devenu courant en historiographie linguistique de qualifier de darwiniste la théorie de Schleicher, alors même qu'on savait depuis longtemps que les idées de Schleicher trouvent leurs origines ailleurs et qu'elles naissent bien avant qu'il se familiarise avec le darwinisme. Aux yeux de ses détracteurs contemporains en Allemagne, Schleicher n'était pas un héraut du darwinisme, mais du 'matérialisme'. La présente contribution se penche sur ce qu'on entendait par 'matérialisme' en Allemagne au XIXe siècle — du point de vue philosophique ainsi que politique — et identifie la raison pour laquelle les critiques de Schleicher le taxaient de matérialiste. Seront analysées les théories de Schleicher dans les domaines de la linguistique et de la philosophie des sciences, ainsi que la critique qu'elles essuyaient de la part de H. Steinthal (1823-1899). Ensuite, cet article va enquêter sur le courant contemporain du matérialisme scientifique et explorera le lien entre cette mouvance et les idées politiques et philosophiques ainsi que les origines sociales de Schleicher.

\section{ZUSAMMENFASSUNG}

In seinem Spätwerk versuchte August Schleicher (1821-1868), der als führende Figur der Indogermanistik Mitte des 19. Jahrhunderts gilt, Parallelen zwischen der Sprachwissenschaft und der damals noch neuen Evolutionstheorie Darwins zu ziehen. Infolgedessen ist es in der Geschichte der Sprachwissenschaft üblich geworden, Schleicher als Darwinisten zu bezeichnen, obwohl es schon lange bekannt war, dass die Ansichten Schleichers anderen Ursprungs und schon vor seiner Bekanntschaft mit dem Darwinismus entstanden sind. Für seine kritischen Zeitgenossen in Deutschland war Schleicher kein Vertreter des Darwinismus, sondern des 'Materialismus'. Dieser Beitrag ergründet den Begriff 'Materialismus' im Kontext der philosophischen und politischen Auseinandersetzungen im Deutschland des 19. Jahrhunderts und ermittelt den Grund für den Materialismusvorwurf gegen Schleicher. Er untersucht die linguistischen und wissenschaftsphilosophischen Theorien Schleichers und die dagegen gerichtete Kritik von H. Steinthal (1823-1899). Anschließend untersucht der Beitrag die zeitgenössische Bewegung des wissenschaftlichen Materialismus und erforscht den Zusammenhang zwischen dieser Bewegung und den politischen und philosophischen Ansichten sowie der sozialen Herkunft Schleichers. 
Author's address:

James McElvenny

Linguistics and English Language

University of Edinburgh

Scotland, United Kingdom

e-mail: james.mcelvenny@mailbox.org 